\title{
Analisis Struktur Patahan Daerah Suoh Menggunakan Metode Gaya Berat dan Penentuan Kerapatan Patahan
}

\author{
Ahmad Zaenudina, Karyanto ${ }^{a}$, Aulia Kurniasiha, Rahmat Catur Wibowo ${ }^{a^{*}}$ \\ aTeknik Geofisika, Fakultas Teknik Universitas Lampung, Indonesia \\ Kec. Rajabasa, Kota Bandar Lampung, Lampung 35141 \\ *Email : rahmat.caturwibowo@eng.unila.ac.id
}

(Diterima 5 Agustus 2021; Disetujui 1 Desember 2021; Dipublikasikan 29 Desember 2021)

\begin{abstract}
Abstrak
Suoh merupakan daerah tektonik aktif yang mengakibatkan terbentuknya struktur geologi yang tersebar di Daerah Suoh. Struktur geologi yang berkembang di Daerah Suoh telah dianalisis menggunakan data gaya berat dan data DEM ALOS PALSAR untuk menentukan dan menganalisis struktur geologi serta arah dominannya. Analisis struktur bawah permukaan menggunakan metode gaya berat dengan analisis Second Vertical Derivative (SVD) dan analisis kelurusan menggunakan metode Fault Fracture Density (FFD). Kontur SVD residual bernilai 0 dan area dengan nilai FFD tinggi ( 2 sampai 2,6 km/ $\mathrm{km}^{2}$ ) mengindikasikan adanya struktur sesar dangkal. Berdasarkan analisis kelurusan data DEM telah didapatkan informasi tentang kelurusan berarah barat laut-tenggara yang sangat jelas, selaras dengan struktur geologi regional daerah Suoh.
\end{abstract}

Kata kunci: Lineament, patahan, Suoh, FFD.

\section{Latar Belakang}

Zona sesar Sumatera terdiri dari beberapa segmen sesar yang umumnya memiliki batas di daerah depresi. Sesar Sumatera tersegmentasi kedalam 19 buah segmen. Salah satu segmen sesar Sumatera adalah segmen Ranau-Suoh [1]. Daerah Panasbumi Suoh terletak di sebelah selatan Gunung Sekincau, Lampung Barat. Daerah panasbumi ditandai dengan adanya sebaran mata air panas akibat terbentuknya patahan di Kaldera [2]. Struktur geologi seperti patahan dan rekahan seringkali mempunyai ciri tertentu di permukaan bumi seperti kelurusan [3] dan patahan utama berasosiasi dengan suhu permukaan tanah yang tinggi di daerah potensi panasbumi [4]. Gambar 1 memperlihatkan patahan Daerah Suoh yang merupakan bagian dari Sesar Sumatera dalam segmen Sesar Semangko.

Pada Daerah Suoh telah banyak dilakukan penelitian mengenai struktur geologi sebelumnya. Penelitian sebelumnya oleh Iqbal dan Juliarka (2019)[5] tentang struktur geologi Daerah Suoh dilakukan dengan menggunakan metode FFD. Berdasarkan dua studi tersebut, Daerah Suoh memiliki permeabilitas baik yang ditunjukan dengan nilai densitas kelurusan yang tinggi hingga sedang seperti di Danau Suoh dan Bukit Penetoh. Mengacu dari penelitian sebelumnya maka dilakukanlah penelitian ini dengan menekankan pada analisis kelurusan atas permukaan berdasarkan dari data Digital Elevation Map (DEM) dan data gaya berat berdasarkan analisis derifatif.

Analisis keberadaan struktur sesar, batas litologi, struktur intrusi, kaldera, dan batas perubahan densitas dilakukan dengan menganalisis kontur anomali gradien horizontal orde 2 anomali Bouguer dengan nilai 0 (nol)[6].

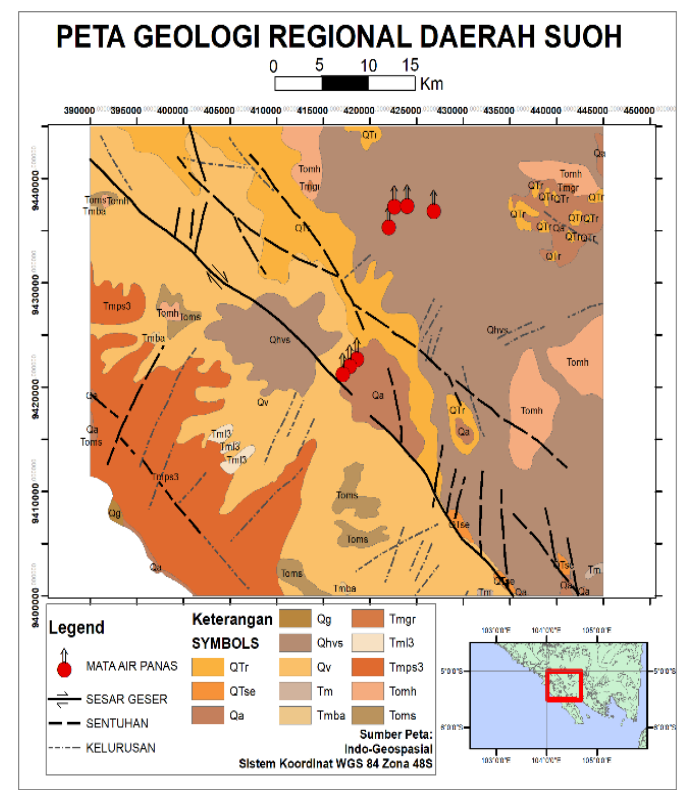

Gambar 1. Peta geologi daerah penelitian (dimodifikasi dari [7]). 
Dari analisis SVD pola-pola sesar yang didapat hasilnya akan identik dengan pola sesar dari pemetaan geologi [8]. Turunan vertikal kedua (SVD) analisis anomali Bouguer dilakukan keluar untuk mendapatkan struktur patahan, litologi batas, dan sumber anomali berasal dari dekat permukaan [9].

Selain itu dilakukan juga analisa geospasial untuk mengetahui kondisi struktur makro dengan analisis FFD. Zona-zona lemah patahan dapat diketahui dengan melakukan perhitungan pola kerapatan garis lineasi dari data citra satelit [10]. Dengan memakai metode FFD, bisa diketahui kelurusan-kelurusan yang berkaitan dengan struktur pada daerah penelitian atau dengan melihat refleksi topografi seperti kelurusan sungai, kelurusan lembah, struktur sesar maupun rekahan. Kemunculan nilai FFD yang tinggi menandakan adanya zona patahan, kontras material batuan keras dan lunak, atau batuan sedimen yang lapisannya menghunjam ke arah dataran rendah [11].

\section{Metodologi}

Tahapan awal yang dilakukan sebagai persiapan adalah melakukan pengumpulan data. Selain studi literatur tentang informasi geologi regional, juga dikumpulkan data gaya berat sekunder dan data DEM Daerah Suoh. Data gaya berat udara bebas didapat secara free access dari data satelit TOPEX dan data DEM. Data gaya berat sekunder Free-Air Anomaly (FAA) harus dikoreksi untuk menghasilkan nilai anomali Bouguer lengkap. Pertama-tama dilakukan koreksi Bouguer akibat efek tarikan dari material/massa yang berada diantara statiun dan bidang datum yang belum diperhitungkan. Koreksi Bouguer dilakukan dengan menggunakan pendekatan benda berupa slab tak berhingga dengan ketebalan dan densitas yang sama. Nilai rapat massa rata-rata di daerah penelitian dapat ditentukan dengan perhitungan Netlleton dan Parasnis. Setelah didapatkan nilai densitas yang akan digunakan pada koreksi Bouguer (BC), maka anomali FAA akan dikurangkan dengan nilai $\mathrm{BC}$ yang menghasilkan nilai anomali Bouguer sederhana (SBA). Kemudian ditambahkan koreksi medan atau Terrain Correction (TC) terhadap anomali gaya berat karena bersifat mengurangi. Barulah akan didapatkan Complete Bouguer Anomaly (ABL). Nilai ABL kemudian diolah menggunakan perangkat lunak Geosoft, sehingga didapatkan peta anomali Bouguer daerah penelitian (Gambar 2).

Metode yang digunakan untuk memisahkan anomali regional dan residual adalah moving average. Untuk mendapatkan nilai lebar jendela yang akan digunakan maka dibuat slicing dengan arah timur-barat pada daerah penelitian. Dari 5 lintasan, diperoleh nilai interval jarak dan sampel data slicing. Dari masing-masing data slicing ABL dilakukan analisis spektral dengan menerapkan proses Fourier transform yang mengandung nilai riil dan imajiner sehinga diperoleh nilai absolutnya. Setelah itu akan didapatkan nilai frekuensi ${ }_{2}$ dari nilai bilangan gelombang $(k)$ dengan cara mengalikan nilai frekuensi dengan $2 \pi$. Dicari juga nilai Ln $A$ dengan menggunakan rumus Ln nilai absolut. Analisis spektrum anomali Bouguer dilakukan untuk menentukan batas kedalaman anomali regional dan residual. Hasil analisis spektrum digunakan untuk mendapatkan batas kedalaman nilai anomali Bouguer regional residual [12].

Selanjutnya diplot nilai $k$ sebagai sumbu $x$ dan Ln $A$ sebagai sumbu $y$. Pada proses ini didapatkan nilai lebar jendela sebesar 25. Setelah anomali residual dan regional terpisah, maka dilakukan analisis turunan. First Horisontal Derivative (FHD) dan Second Vertical Derivative (SVD) diterapkan pada data residual dan hasilnya dicocokan dengan peta geologi regional Daerah Suoh. Dilakukan slicing lintasan pada daerah yang diperkirakan terdapat keberadaan patahan yang nampak dari peta kontur anomali residual.

Filter SVD operasi matriks [13] diterapkan dengan menggunakan persamaan 1 yang merupakan nilai respon amplitudo perhitungan Elkins. Nilai matriks operasi $5 \times 5$ pada persaman 2 ini yang digunakan sebagai nilai perhitungan operasi matriks untuk filter SVD sehingga diperoleh peta kontur SVD (Gambar 5).

$$
S V D=\frac{g(i+1)-2 g(i)+g(i+1)}{\Delta x^{2}}
$$

$\left[\begin{array}{ccccc}0.0000 & -0.0833 & -0.0667 & -0.0833 & 0.0000 \\ -0.0833 & -0.0667 & -0.0334 & -0.0667 & -0.0833 \\ 0.0000 & -0.0334 & 1.0667 & -0.0334 & 0.0000 \\ -0.0833 & -0.0667 & -0.0334 & -0.0667 & -0.0833 \\ 0.0000 & -0.0833 & -0.0667 & -0.0833 & 0.0000\end{array}\right]$


Kemudian, dengan menggunakan data DEM dibuat citra shaded relief dari DEM dengan menggunakan berbagai arah pencahayaan $\left(0^{\circ}, 45^{\circ}\right.$, $90^{\circ}$, dan $135^{\circ}$ ) untuk meningkatkan ketajaman visualisasi dari permukaan bumi. Selanjutnya dilakukan ekstraksi kelurusan atau lineament secara otomatis untuk menentukan pola dominan dari kelurusan. Kemudian mengkombinasikan empat citra shaded relief dari berbagai arah pencahayaan, sehingga diperoleh satu citra kombinasi yang bertujuan agar lebih memperlihatkan detail dari struktur geologi dari berbagai arah sudut pandang. Proses ekstraksi kelurusan berdasarkan data DEM dilakukan secara otomatis dengan algoritma LINE pada perangkat lunak PCI Geomatica. Algoritma LINE ini dibedakan menjadi tiga tahapan yaitu tahap edge detection, thresholding, dan ekstraksi kurva. Pembuatan peta densitas lineament dilakukan dengan menerapkan fungsi line density pada lineament hasil ekstraksi.

\section{Hasil dan Pembahasan}

Anomali Bouguer pada Gambar 2 adalah superposisi dari anomali yang bersifat regional dan yang bersifat residual atau lokal [14]. Peta anomali Bouguer di daerah penelitian menunjukkan rentang nilai anomali antara $-40 \mathrm{mGal}$ sampai 90 mGal. Hasil tersebut merupakan respon variasi rapat massa batuan yang ada pada daerah tersebut. Gradasi warna pada peta menunjukkan varisi nilai anomali Bouguer yang terdapat pada daerah penelitian. Pada peta dapat dibedakan menjadi 3 kelompok warna. Warna ungu muda sampai hijau tua menunjukkan nilai anomali rendah (-40 sampai $30 \mathrm{mGal}$ ), tersebar pada bagian timurlaut daerah penelitian yang memanjang dengan ke arah relatif timurlaut - tenggara, anomali rendah di bagian tengah ini dipengaruhi oleh batuan gunungapi Kuarter Muda. Selanjutnya warna hijau muda sampai pada warna jingga menunjukkan anomali sedang (30 sampai $60 \mathrm{mGal}$ ) yang terdapat di daerah barat daerah penelitian yang tersebar hampir diseluruh daerah penelitian dengan arah relatif barat laut-tenggara, anomali sedang ini dipengaruhi oleh tuf Ranau. Sedangkan warna jingga sampai merah menunjukkan anomali tinggi (60 sampai $90 \mathrm{mGal}$ ) yang terdapat di daerah selatan-barat laut, anomali tinggi ini dipengaruhi oleh batuan gunungapi Kuarter Tua.

Dari peta ABL daerah penelitian dilakukan proses filter moving average, maka perlu dilakukan analisis spektral. Dilakukan slicing sebanyak lima lintasan yang mewakili nilai anomali pada daerah penelitian untuk selanjutnya ditransformasi Fourier menggunakan Microsoft Excel. Tujuan dari analisis spektrum ialah untuk mendapatkan nilai kemiringan (gradien) yang berasal dari log power spektrum (Ln Amplitudo) dengan nilai frekuensi $(k)$. Nilai $k$ dan $\operatorname{Ln} A$ diplot kedalam grafik untuk mengetahui kedalaman bidang diskontinuitas, lalu mendapatkan lebar jendela dan estimasi kedalaman zona regional dan juga residual pada daerah penelitian. Sebaran data $k$ vs Ln $A$ akan membentuk suatu fungsi linier. Data yang memiliki kontras perbedaan yang signifikan dapat diidentifikasi sebagai batas antara zona regional dan zona residual [15]. Selanjutnya didapatkan dua persamaan pada zona regional dan residual yang mengandung informasi kedalaman. Selanjutnya dicari nilai cut off (Kc), lalu dicari nilai lamda, kemudian dicari nilai lebar jendela $(\mathrm{N})$ dengan cara membagi nilai lambda dengan interval jarak sampling lintasan slicing sebesar 400 meter. Nilai kedalaman bidang diskontinuitas dalam dan dangkal kelima lintasan ditunjukan dalam Tabel 1. Rata-rata kedalaman bidang diskontinuitas dalam adalah 6,14 km dan diinterpretasikan sebagai ratarata kedalaman batuan basement yang materialnya lebih padat sehingga memiliki kontras densitas yang berbeda. Sedangkan rata-rata kedalaman

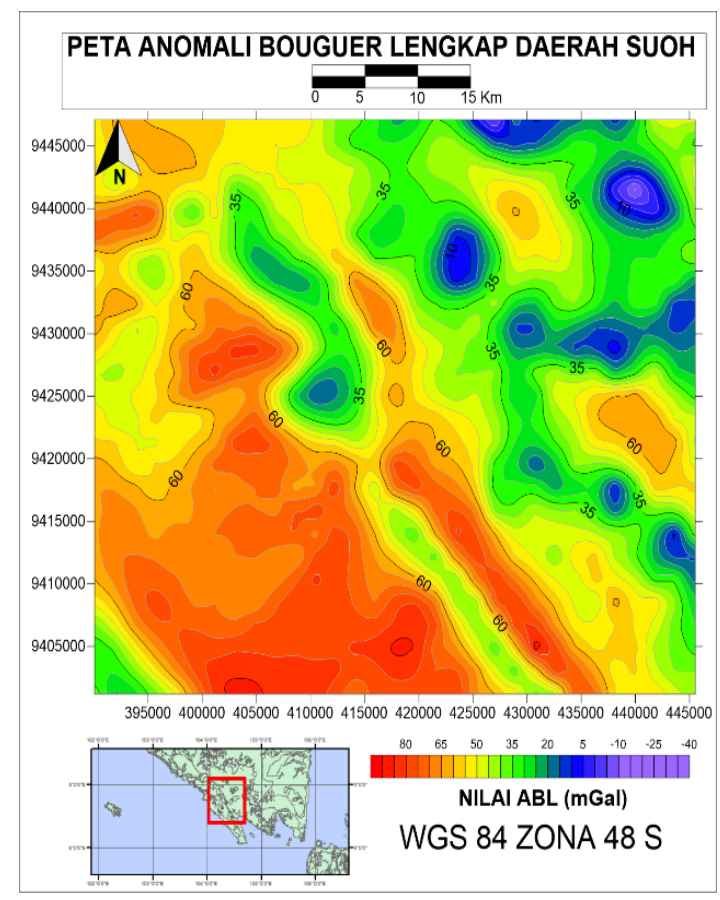

Gambar 2. Peta Anomali Bouguer Lengkap (ABL) Daerah Suoh. 
POSITRON Vol. 11, No. 2 (2021), Hal. 95 - 103

Tabel 1. Perhitungan nilai lebar jendela analisis spektral

\begin{tabular}{|c|c|c|c|c|c|c|c|}
\hline Lintasan & Regional (m) & Residual (m) & C1 & C2 & Cutt off & Lambda & N \\
\hline 1 & -5893 & $-491,71$ & 7,8549 & 4,915 & 0,000544 & 11543,69 & 28,85 \\
\hline 2 & -4799 & $-642,55$ & 7,5179 & 4,7153 & 0,000674 & 9318,399 & 23,29 \\
\hline 3 & -6004 & $-366,96$ & 7,9473 & 3,7931 & 0,000737 & 8525,966 & 21,31 \\
\hline 4 & $-6560,4$ & $-493,47$ & 8,1037 & 4,0137 & 0,000674 & 9320,207 & 23,30 \\
\hline 5 & $-7478,8$ & $-612,73$ & 7,7585 & 3,5215 & 0,000617 & 10181,92 & 25,45 \\
\hline & $-6147,04$ & $-521,484$ & \multicolumn{5}{|c|}{ Rata - rata } \\
\hline
\end{tabular}

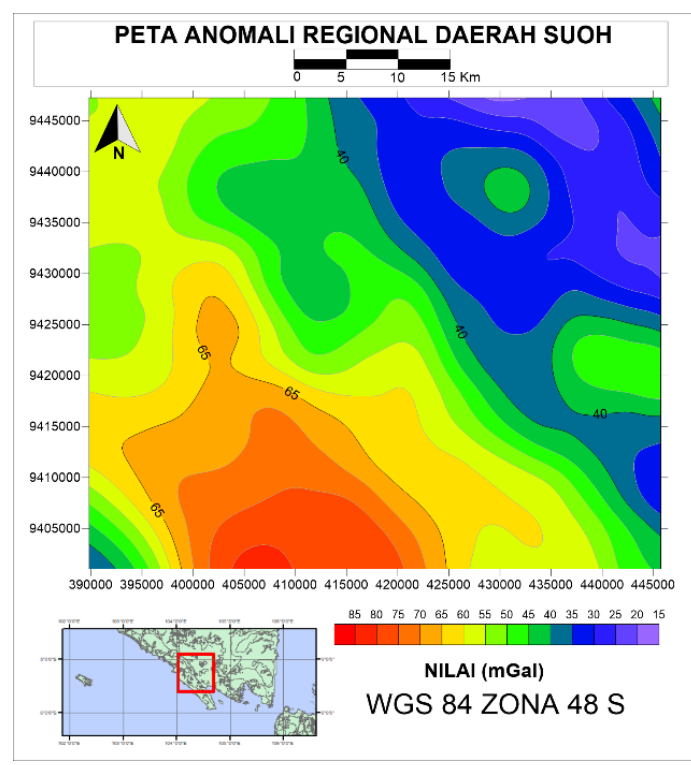

Gambar 3. Peta Anomali Regional Daerah Suoh

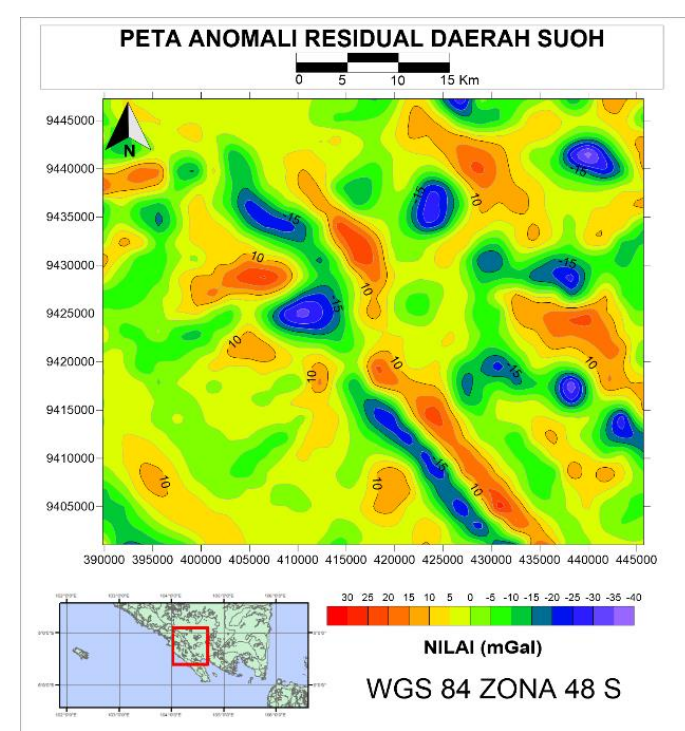

Gambar 4. Peta Anomali Residual Daerah Suoh. bidang diskontinuitas dangkal yang merupakan kedalaman batuan sedimen adalah $521 \mathrm{~m}$. Nilai bilangan gelombang cut off (kc) rata-rata dari kelima penampang lintasan adalah 0,000649 (Tabel 1). Semakin besar grid spasi yang digunakan, maka lebar jendela yang diperoleh akan semakin lebar. Hasil rata-rata lebar jendela dari kelima penampang lintasan adalah $(25 \times 25) \mathrm{km}$. Hasil filter ini merupakan anomali regional (Gambar 3) yang merupakan anomali dalam [12]. Anomali yang bersumber dari bagian dalam bumi contohnya adalah kerak bumi, anomali ini dicirikan dengan frekuensi rendah. Peta anomali regional memiliki nilai anomali sebesar $15 \mathrm{mGal}$ sampai $85 \mathrm{mGal}$.

Anomali residual (Gambar 4) didapatkan dari pengurangan antara Anomali Bouguer Lengkap (ABL) dengan anomali regional. Peta anomali residual menunjukkan pola anomali yang lebih kompleks dibandingkan dengan anomali regional, karena menggambarkan pola anomali dengan panjang gelombang yang lebih pendek yang mencerminkan efek benda anomali yang lebih dangkal, anomali ini dicirikan dengan frekuensi tinggi. Peta anomali residual memiliki rentang nilai sebesar $-40 \mathrm{mGal}$ hingga $30 \mathrm{mGal}$.

Setelah anomali residual didapatkan maka dilanjutkan dengan analisis derivative. Pertamatama akan dilakukan proses penurunan pertama horisontal (FHD) yang dilakukan di software Oasis. Dengan menggunakan filter orde pertama gradien horizontal menghasilkan peta FHD. Dilanjutkan dengan penurunan kedua SVD menggunakan matriks Elkins [13].

SVD anomali residual memiliki letak dan arah patahan relatif sama dengan patahan yang ada pada peta geologi, dimana pada peta SVD arah 


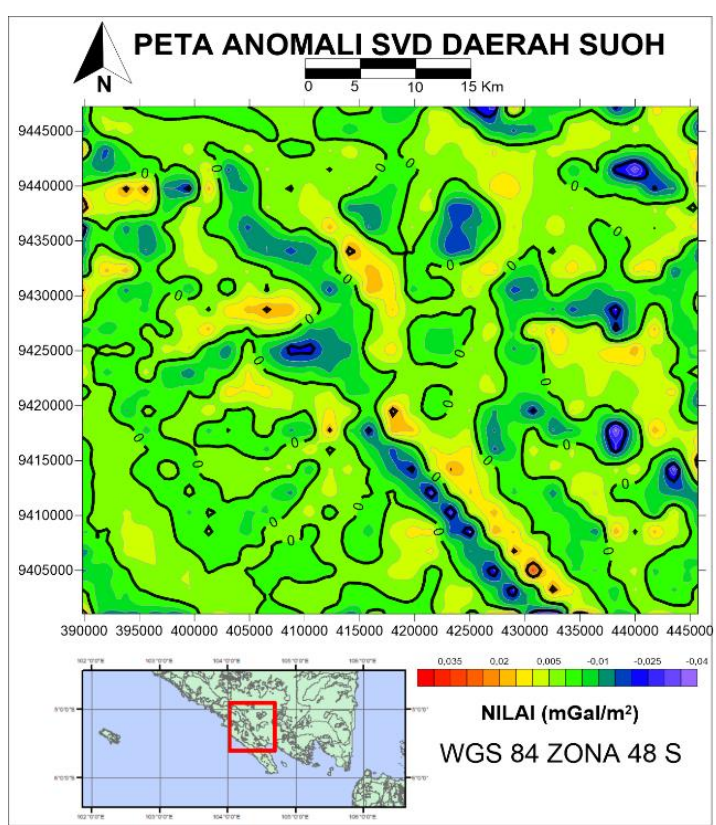

Gambar 8. Peta anomali SVD Daerah Suoh.

dominan dari struktur geologi bawah permukaan mengarah pada barat laut-tenggara (Gambar 5). Kontur 0 yang terdapat pada peta SVD residual selanjutnya dikorelasikan secara visual dengan peta FFD. Korelasi tersebut dilakukan untuk

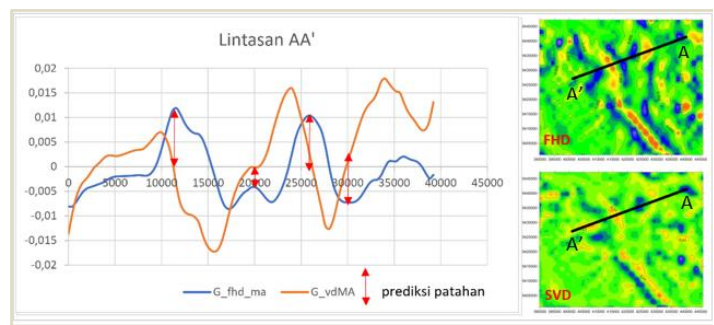

Gambar 5. Grafik FHD dan SVD Lintasan AA'.

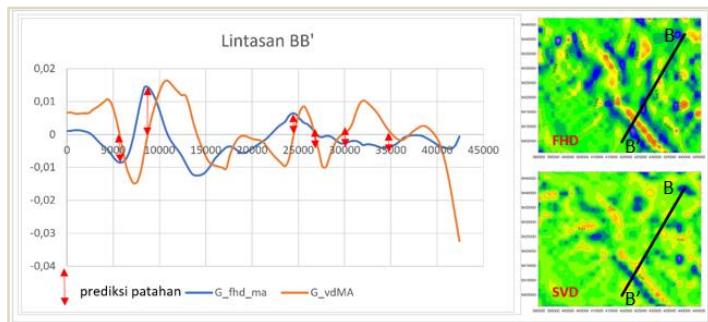

Gambar 6. Grafik FHD dan SVD Lintasan BB'.

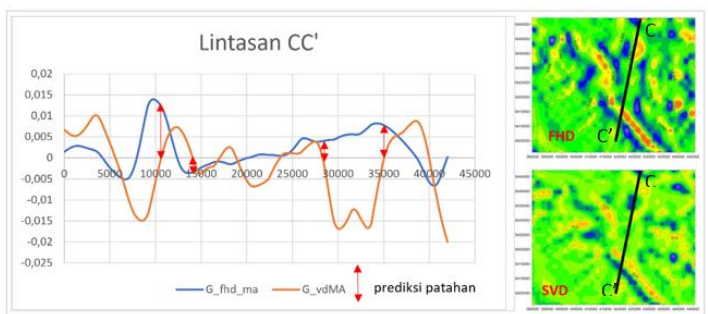

Gambar 7. Grafik FHD dan SVD Lintasan CC'. memvalidasi adanya zona sesar yang terdapat pada daerah penelitian berdasarkan kedua metode tersebut yang masing-masing mewakili kedua data yaitu data gaya berat untuk identifikasi struktur bawah permukaan dan data DEM untuk validasi struktur di atas permukaan.

Pada peta FHD dan SVD dilakukan slicing 3 lintasan. Data slice mengandung informasi nilai koordinat lintang, bujur, interval jarak antar titik sampling slicing, nilai FHD, dan nilai SVD. Nilai interval sampling diplot ke dalam kurva sebagai sumbu $x$, sementara nilai FHD dan SVD sebagai sumbu y seperti pada Gambar 6, 7 dan 8. Kemudian kurva FHD dan SVD disandingkan untuk dianalisis. Keberadaan patahan dilihat dari kurva FHD, sedangkan untuk mengetahui jenis patahan dilihat dengan kurva SVD.

Pada analisis FHD dan SVD lintasan AA' (Gambar 6) sepanjang $40 \mathrm{~km}$, memiliki nilai anomali FHD sebesar $0,0119 \mathrm{mGal} / \mathrm{m}$ dan SVD mendekati nol yaitu $0,0006 \mathrm{mGal} / \mathrm{m}$ pada jarak sekitar $13 \mathrm{~km}$ sehingga diperkirakan terdapat patahan. Selanjutnya pada jarak sekitar $22 \mathrm{~km}, 27$ $\mathrm{km}$, dan $32 \mathrm{~km}$ berturut-turut memiliki nilai anomali FHD sebesar $-0,0045 \mathrm{mGal} / \mathrm{m}, 0,0097$ $\mathrm{mGal} / \mathrm{m}$, dan -0,0072 $\mathrm{mGal} / \mathrm{m}$ serta SVD mendekati nol. Sehingga dapat diperkiraan terdapat patahan.

Lintasan BB' (Gambar 7) sepanjang $42 \mathrm{~km}$, memiliki nilai anomali FHD berturut-turut sebesar $-0,0095 \mathrm{mGal} / \mathrm{m}$ dan $0,0142 \mathrm{mGal} / \mathrm{m}$ dan SVD nol pada jarak sekitar $6 \mathrm{~km}$ dan $8 \mathrm{~km}$ sehingga diperkirakan terdapat patahan. Selanjutnya pada jarak sekitar $24 \mathrm{~km}, 27 \mathrm{~km}, 31 \mathrm{~km}$, dan $35 \mathrm{~km}$ berturut-turut memiliki nilai anomali FHD sebesar $0,0071 \mathrm{mGal} / \mathrm{m},-0,0004 \mathrm{mGal} / \mathrm{m},-0,0019 \mathrm{mGal} / \mathrm{m}$, dan $-0,0028 \mathrm{mGal} / \mathrm{m}$ serta SVD nol. Sehingga dapat diperkiraan terdapat patahan.

Lintasan CC' (Gambar 8) sepanjang $42 \mathrm{~km}$, memiliki nilai anomali FHD berturut-turut sebesar $0,0129 \mathrm{mGal} / \mathrm{m}$ dan $-0,0034 \mathrm{mGal} / \mathrm{m}$ dan SVD nol pada jarak sekitar $11 \mathrm{~km}$ dan $14 \mathrm{~km}$ sehingga diperkirakan terdapat patahan. Selanjutnya pada jarak sekitar $29 \mathrm{~km}$, dan $35 \mathrm{~km}$ berturut-turut memiliki nilai anomali FHD sebesar 0,0040 $\mathrm{mGal} / \mathrm{m}$, dan $0,0075 \mathrm{mGal} / \mathrm{m}$ serta SVD nol. Sehingga dapat diperkiraan terdapat patahan.

Pada analisis data DEM citra ALOS PALSAR yang diolah dengan software ArcGIS, digunakan algoritma shaded relief. DEM mewakili kondisi permukaan bumi sebenarnya tanpa distorsi dengan variasi-variasi tertentu dapat dilakukan seperti 
perubahan posisi matahari (altitude) dan sudut pencahayaan (azimuth). Data DEM terlebih dahulu di proses hillshade di software ArcGIS untuk mendapatkan efek tiga dimensi (3D) sehingga bentuk relief terlihat. Data raster yang masih dalam format 2D diberikan kesan 3D pada data raster tersebut. Pemberian kesan 3D tersebut dapat dilakukan dengan menggunakan teknik penajaman pencahayaan dan bayangan yang tepat pada sebuah data raster [16]. Dari proses ini akan didapatkan empat citra DEM dengan sun azimuth masing masing sebesar $0^{\circ}, 45^{\circ}, 90^{\circ}$ dan $135^{\circ}$. Setelah diberikan hillshade maka reliefnya akan lebih terlihat jelas, sehingga penampakan visual dari suatu kelurusan dapat terlihat. Proses hillshade dapat meningkatkan akurasi ekstraksi kelurusan secara otomatis menggunakan algorithma LINE [17].

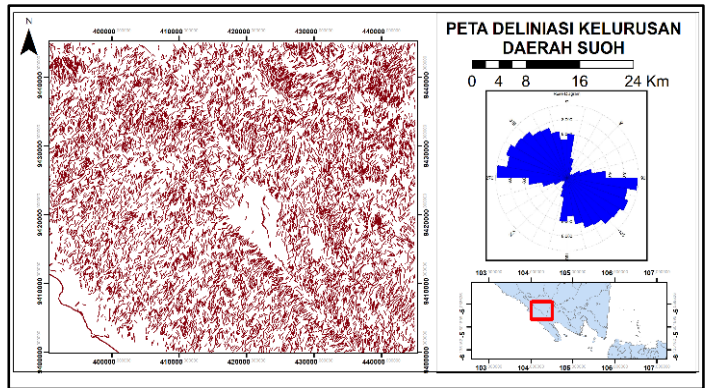

Gambar 9. Peta kelurusan Daerah Suoh.

Peta shade relief selanjutnya dilakukan ekstraksi lineament. Proses penentuan garis lineament dilakukan secara otomatis dikarenakan cakupan daerah penelitian yang luas. Ekstraksi lineament dilakukan secara otomatis dengan menggunakan software PCI Geomatica. Algoritma LINE terdiri dari tiga tahap: edge detection, thresholding, dan ekstraksi kurva. Hasil garis ekstraksi lineament bergantung pada nilai parameter yang dimasukan dalam software PCI

Tabel 2. Parameter ekstraksi kelurusan otomatis.

\begin{tabular}{|c|c|}
\hline Jenis Parameter Input & $\begin{array}{c}\text { Nilai } \\
\text { Ekstraksi }\end{array}$ \\
\hline RADI (Filter Radius) & 15 Pixel \\
\hline GTHR (Gradient Threshold) & 60 Pixel \\
\hline LTHR (Length Threshold) & 20 Pixel \\
\hline $\begin{array}{c}\text { FTHR (Line Fitting Error } \\
\text { Threshold) }\end{array}$ & 3 Pixel \\
\hline $\begin{array}{c}\text { ATHR (Angular Difference } \\
\text { Threshold) }\end{array}$ & $30^{\circ}$ \\
\hline $\begin{array}{c}\text { DTHR (Linking Distance } \\
\text { Threshold) }\end{array}$ & 10 Pixel \\
\hline
\end{tabular}

Geomatica. Enam parameter ini antara lain yaitu Tabel 2. Dilakukan beberapa input variasi nilai parameter (threshold) yang dipilih berdasarkan beberapa referensi acuan juga dengan memperkirakan hasil fitur kelurusan yang paling sesuai dan mencerminkan struktur geologi (patahan maupun rekahan).
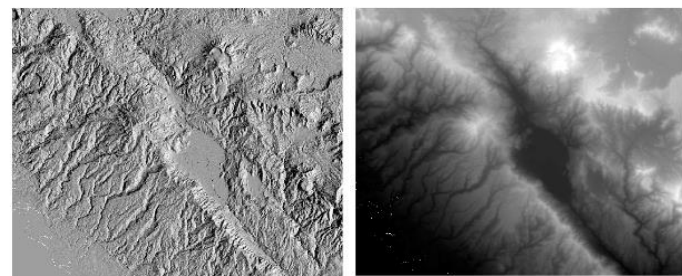

Gambar 11. Shade relief pada data DEM.

Karakteristik patahan maupun rekahan yang dijadikan bahan pertimbangan ialah panjang, kelengkungan, segmentasi, separasi, arah dan sebagainya. Penentuan arah dari suatu kelurusan hasil ekstraksi yaitu data kelurusan tersebut dikonversi menjadi diagram roset. Diagram roset akan merepresentasikan nilai kelurusan berdasarkan parameter vektor (arah dan besaran) fenomena itu dalam arah tertentu dan banyaknya jumlah kejadian.

Data DEM hillshade dengan sudut sun azimuth yang berbeda-beda menghasilkan arah kelurusan yang berbeda. Pada data DEM yang telah diberi shade relief lalu dilakukan deliniasi kelurusannya secara otomatis menghasilkan arah dominan kelurusan $\mathrm{N} 130^{\circ} \mathrm{E}$, yaitu pada arah barat laut-tenggara seperti pada (Gambar 11). Berdasarkan hasil analisis tersebut pada arah kelurusan ini selaras dengan struktur struktur geologi yang terdapat pada daerah penelitian.

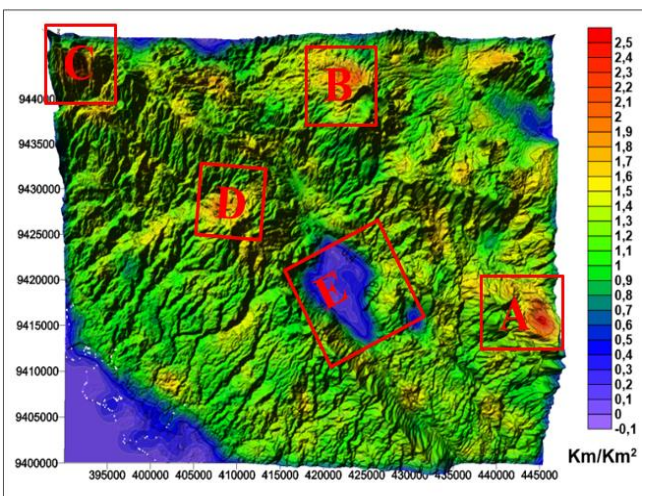

Gambar 10. Peta densitas kelurusan (FFD) Daerah Suoh. 
Karena pola sesar pada Daerah Suoh yaitu sesar berarah barat laut-tenggara. Dari diagram roset dapat dilihat bahwa kelurusan yang dihasilkan secara otomatis menggunakan algoritma LINE hanya dapat mengidentifikasi arah kelurusan yang dominan.

Selanjutnya dilakukan perhitungan densitas kelurusan akan menghitung panjang dari kelurusan per satu kilometer, semakin panjang (rapat) kelurusan dalam satu kilometer maka akan tinggi nilai desitasnya [18]. Peta kerapatan kelurusan (lineament density) pada Gambar 11 memberikan informasi mengenai anomali kerapatan patahan dan rekahan yang digunakan untuk memprediksi adanya zona lemah yang terdapat banyak patahan atau sesar.

Semakin besar tingkat kerapatan lineament maka semakin menunjukan adanya sesar. Daerah yang memiliki anomali kerapatan kelurusan paling tinggi diindikasikan dengan adanya struktur sesar. Struktur sesar tersebut berasosiasi dengan kelurusan-kelurusan yang ada di daerah tersebut yang merefleksikan gambaran dari topografi berupa kelurusan sungai, kelurusan lembah, struktur sesar maupun rekahan, dan kontak batuan [11].

Daerah penelitian dikelompokkan menjadi empat kelas densitas, yaitu densitas tinggi (2 sampai $2,6 \mathrm{~km} / \mathrm{km}^{2}$ ) yang ditunjukkan dengan warna merah, densitas sedang (1 sampai 1,9 $\mathrm{km} / \mathrm{km}^{2}$ ) yang ditunjukkan dengan warna hijaujingga, densitas rendah $\left(-0,1\right.$ sampai $\left.0,9 \mathrm{~km} / \mathrm{km}^{2}\right)$ dengan warna hijau tua- ungu.

Peta FFD berdasarkan hasil lineament density (Gambar 11) memperlihatkan wilayah dengan densitas tinggi (wilayah A, B dan C), densitas sedang (wilayah D), dan densitas rendah (wilayah E). Wilayah A, B dan C memiliki kelurusan yang rapat sehingga nilai densitas tinggi, ini artinya daerah tersebut diprediksi terdapat rekahan yang mana merupakan daerah tempat keluarnya manifestasi panasbumi. Dengan kata lain wilayah ini yang memiliki permeabilitas baik yang disebut sebagai zona lemah. Data geologi yang mendukung ialah bahwa wilayah B (daerah Gunung Sekincau) tersusun oleh batuan vulkanis dengan umur relatif muda (kuarter) dan terdapat beberapa manifestasi mata air panas. Manifestasi mata air panas yang keluar disebabkan adanya bentukan kawah hasil erupsi Gunung Sekincau tua, sehingga timbul patahan atau struktur sesar normal di sekitar zona depresi kawah. Oleh karena itu dapat dilihat banyak bentuk kelurusan di sekitar lereng gunung menyebabkan tingginya densitas kelurusan di daerah tersebut. Pada wilayah A dan C meskipun tidak terdapat manifestasi seperti mata air panas, hal yang menyebabkan densitasnya tinggi diprediksi akibat banyak terdapat sesar yang terpetakan oleh peta regional.

Selain itu, wilayah D memiliki kelurusan yang tidak lebih rapat dari wilayah A, B dan C sehingga nilai densitasnya sedang. Pada wilayah tersebut tidak terdapat manifestasi seperti mata air panas, mengingat wilayah ini tidak termasuk dalam batas sistem geothermal di Suoh-Sekincau. Pada wilayah ini terdapat sesar yang terpetakan oleh peta regional.

Pada wilayah E merupakan wilayah dengan densitas rendah. Wilayah $\mathrm{E}$ memiliki sedikit kelurusan sehingga nilai densitas rendah, ini artinya daerah tersebut diprediksi tidak banyak terdapat rekahan. Wilayah E merupakan Danau Suoh yang berbentuk cekungan yang bertipe pullapart akibat struktur sesar atau patahan mendatar dari segmen Semangko. Terdapat beberapa manifestasi mata air panas di sekitar zona lemah Danau Suoh, akibat dari patahan, rekahan, juga kontak batuan dalam hal ini batuan endapan Aluvium dengan Formasi Hulusimpang.
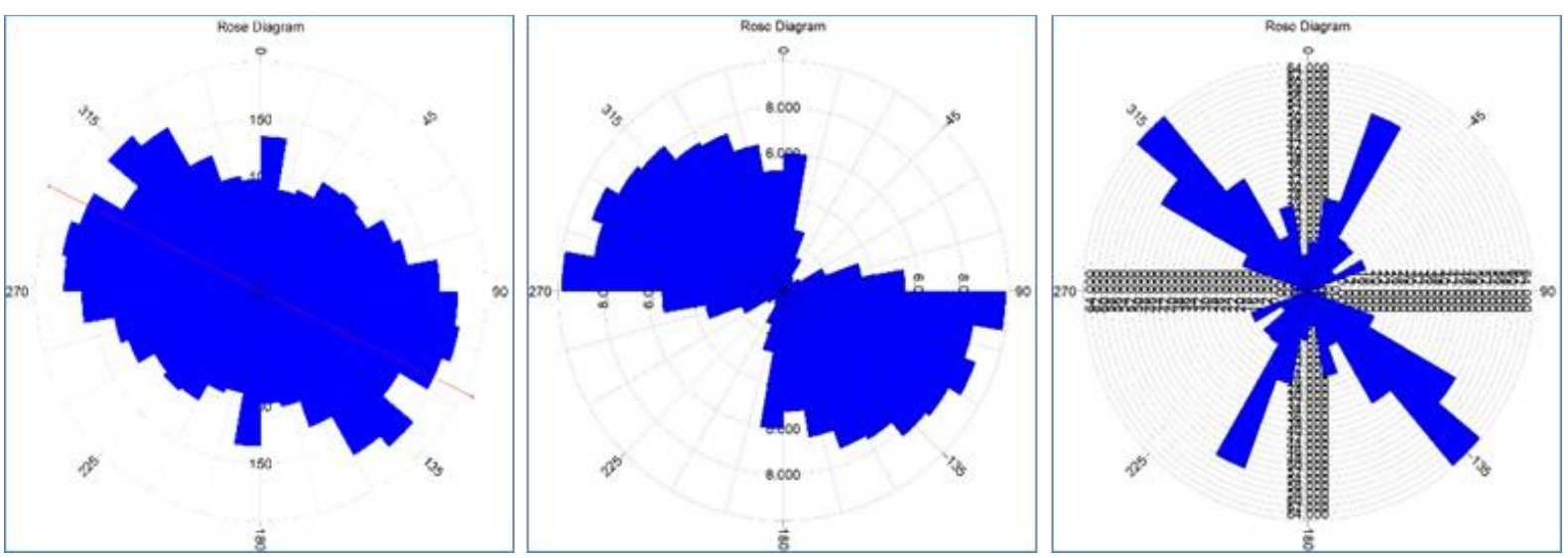

Gambar 12. Diagram roset (a) SVD (b) deliniasi kelurusan (c) struktur geologi. 
Berdasarkan perhitungan kelurusan dari metode SVD, analisis lineament, dan struktur geologi regional diplot pada suatu diagram roset yang dapat dilihat pada Gambar 12. Dasar perhitungan diagram roset memperhitungkan panjang kelurusan pada arah tertentu yang dibandingkan dengan total kelurusan yang ada. Dapat dilihat pada diagram roset yang yang dihasikan bahwa arah dari kelurusan di daerah penelitian menunjukan kesamaan arah dominan baratlaut-tenggara. Arah ini sesuai dengan arah dari tegasan utama Pulau Sumatera yang dikontrol oleh Sesar Besar Sumatera yang juga berarah baratlaut-tenggara.

\section{Kesimpulan}

Terdapat beberapa area yang kerapatan patahannya tinggi (2 sampai $2,6 \mathrm{~km} / \mathrm{km}^{2}$ ) pada peta FFD mengindikasikan adanya struktur patahan dangkal. Struktur patahan pada Daerah Suoh berdasarkan analisis SVD, deliniasi kelurusan menghasilkan informasi orientasi kelurusan berarah barat laut-tenggara, selaras dengan struktur geologi regional Daerah Suoh.

\section{Ucapan Terima Kasih}

Penulis mengucapkan terima kasih kepada TOPEX dan DEMNAS yang telah mendukung ketersediaan data sehingga dapat digunakan bagi penelitian ini. Juga kepada pihak-pihak terkait yang telah memberi dukungan terhadap penelitian ini.

\section{Referensi}

[1] Bellier, O., Bellon, H., Sébrier, M., Sutanto. and Maury, R. C., K-Ar age of the Ranau Tuffs: Implications for the Ranau caldera emplacement and slip-partitioning in Sumatra (Indonesia), Tectonophysics, 312(2-4), pp. 347-359, 1999.

[2] Zaennudin, A., Wahyudin, D., Surmayadi, M. and Kusdinar, E., Prakiraan bahaya letusan Gunung Api Ijen Jawa Timur, J. Lingkung. dan Bencana Geol, 3(2), pp. 109-132, 2012.

[3] Massinai, M. A. and Syamsuddin, R., Struktur Geologi Sulawesi Barat Ditinjau dari Kelurusan Geomorfologi Regional, J. Geod. Undip, 2(3), pp. 62-65, 2018.

[4] Qin, Q., Zhang, N., Nan, P. and Chai, L., Geothermal area detection using Landsat ETM+ thermal infrared data and its mechanistic analysis-A case study in Tengchong, China, Int. J. Appl. Earth Obs. Geoinf., 13(4), pp. 552-559, 2011.

[5] Iqbal, M. and Juliarka, B. R., Analisis
Kerapatan Kelurusan (Lineament Density) di Lapangan Panasbumi Suoh-Sekincau, Lampung, J. Sci. Appl. Technol, 3(2), pp. 61, 2019.

[6] Sarkowi, M., Wibowo, R. C. and Karyanto, Geothermal Reservoir Identification in Way Ratai Area Based on Gravity Data Analysis Geothermal Reservoir Identification in Way Ratai Area Based on Gravity Data Analysis, J. Phys. Conf. Ser, 2110, 2021.

[7] Amin, W. G. T. C., Sidarto. dan Santosa, S., Peta Geologi Lembar Kotaagung, Sumatera: Geological Map of the Kotaagung Quadrangle, Sumatera, Pusat Penelitian dan Pengembangan Geologi, Bandung, 1993.

[8] Zaenudin, A., Sarkowi, M., Pambudi, G. and Sinambela, R. Z., Analisis Zona Mineralisasi Emas Dengan Metode Derivative dan Pemodelan 3D Anomali Gayaberat, Studi Kasus: Pongkor, Jawa Barat, Semin. Nas. AVoER XI 2019, May, pp. 23-24, 2019.

[9] Sarkowi, M., Sawitri, R. F., Mulyatno, B. S. and Wibowo, R. C., Wai Selabung geothermal reservoir analysis based on gravity method, 10(2), pp. 45-63, 2021.

[10] Shandini, Y., Mouzong, M. P., Onguene, R., Tomedi, M. E., Etame, J. and Essimbi, B. Z., Automatic extraction and geospatial analysis of lineaments and their tectonic significance in south Cameroon area using remote sensing techniques and GIS, Anu. do Inst. Geociencias, 43(4), pp. 319-329, 2020.

[11] Suryantini. and Wibowo, H., Application of Fault and Fracture Density (FFD) Method for Geothermal Exploration in Non-Volcanic Geothermal System; a Case Study in Sulawesi-Indonesia, Proc. World Geotherm. Congr, April, pp. 25-29, 2010.

[12] Sarkowi, M. and Wibowo, R. C., Reservoir Identification of Bac-Man Geothermal Field Based on Gravity Anomaly Analysis and Modeling, J. Appl. Sci. Eng, 25(2), pp. 329338, 2021.

[13] Elkins, T. A., The second derivative method of gravity interpretation, Geophysics, 16(1), pp. 29-50, 1951.

[14] Setiadi, N. D., Diyanti, I. dan Ardi, A., Interpretasi Struktur Geologi Bawah Permukaan Daerah Leuwidamar Berdasarkan Analisis Spektral Data Gaya Berat, J. G. S. M., 15(4), pp. 205-214, 2014.

[15] Blakely, R. J., Potential Theory in Gravity and Magnetic, 1996.

[16] Richards, J. A. dan Jia, X., Remote Sensing and Image Analysis 4th Edition, SpringerVerlag, New York, 2006. 
POSITRON Vol. 11, No. 2 (2021), Hal. 95 - 103

[17] Nugroho, U. C. dan Susanto., Ekstraksi Kelurusan ( Linement ) Secara Otomatis Menggunakan Data DEM SRTM Studi Kasus : Pulau Bangka, Proc. Pertem. Ilm. Tah. XX, 1,

[18] Silverman, B. W., Density Estimation for Statistics and Data Analysis, Champman and Hall, New York, 1986. pp. 775-780, 2015. 